\title{
Book Review: International Marine Mammal Law
}

\author{
Christian T. K.-H. Stadtländer* \\ Independent Researcher, Minneapolis, MN, United States
}

Keywords: ecosystem protection, International Marine Mammal Law and Policy, Law of the Sea, marine mammals, marine mammal protection, ocean governance and management

\section{A Book Review on}

\section{International Marine Mammal Law}

Nikolas Sellheim (Cham: Springer Nature Switzerland AG), 2020, xxvii + 225 pages, ISBN: 978-3030-35267-7

Marine mammals (i.e., dolphins, dugongs, manatees, polar bears, porpoises, sea lions, seals, sea otters, walruses, and whales) play a vital role in the food web of marine ecosystems and are considered "key indicators of the overall health of the ocean" [National Oceanic and Atmospheric Administration (NOAA), 2020]. The awareness of threats to these animals due to human activities has led to the ratification of numerous regional and global legal regimes aimed at the conservation, management, and study of marine mammals. Some key instruments include the following:

- International Convention for the Regulation of Whaling (ICRW) [International Whaling Commission (IWC), 1946]

- Marine Mammal Protection Act (MMPA) [U.S. Fish and Wildlife Service (FWS), 1972]

- Endangered Species Act (ESA) [U.S. Fish and Wildlife Service (FWS), 1973]

- Agreement on the Conservation of Polar Bears (ACPB) (Polar Bear Range States, 1973)

- Convention on International Trade in Endangered Species of Wild Fauna and Flora (CITES) (CITES.org., 1975)

OPEN ACCESS

Edited and reviewed by: Rob Harcourt, Macquarie University, Australia

${ }^{*}$ Correspondence:

Christian T. K. -H. Stadtländer ctkstadtlander@msn.com

Specialty section: This article was submitted to Marine Affairs and Policy, a section of the journal

Frontiers in Marine Science

Received: 03 February 2021

Accepted: 23 August 2021

Published: 16 September 2021

Citation:

Stadtländer CTK-H (2021) Book Review: International Marine Mammal

Law. Front. Mar. Sci. 8:663784.

doi: 10.3389/fmars.2021.663784
- UN Convention on the Law of the Sea (UNCLOS) (United Nations, 1982)

- Agreement on Cooperation in Research, Conservation and Management of Marine Mammals in the North Atlantic ("NAMMCO-Agreement") [North Atlantic Marine Mammal Commission (NAMMCO), 1992]

- Marine Mammal Regulations (MMR) (Department of Justice, Canada, 1993)

- Agreement for the Creation of a Mediterranean Sanctuary for Marine Mammals ("Pelagos Sanctuary Agreement”), 1999 (see English translation: Notarbartolo-Di-Sciara et al., 2008).

Sellheim (2020), who holds a doctorate in law, coined the term "International Marine Mammal Law" (IMML) to describe the complex legal landscape for marine mammal conservation and sustainable use. The book, which contains nine chapters, is unique in that he not only discussed the various threats to marine mammals, their population status, and the rules of law that govern their conservation and management but also the cultural perceptions and misconceptions about these animals. In other words, he wrote a book about issues that lie at the interface among marine mammal science, society, regional/global law, and policy.

Sellheim (2020) pointed out in the first chapter that IMML is primarily concerned with the law that has been agreed on between nation-states and that is part of international environmental law, which emerged in the 1960s. He described the global and regional environmental cooperation that increased after the establishment of the United Nations in 1945, which led to the drafting of key regimes for the conservation of the environment, including the instruments I have mentioned earlier. 


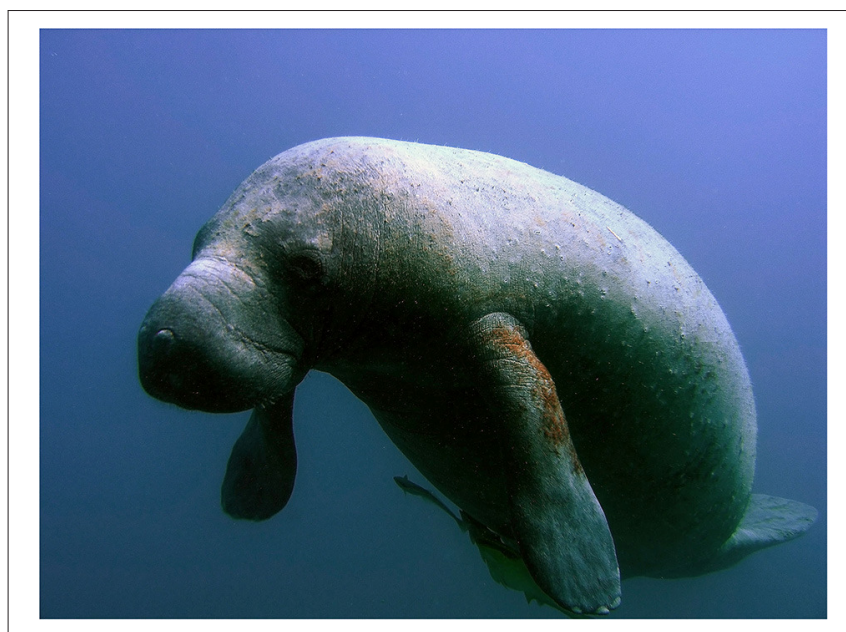

FIGURE 1 | Manatee (Trichechus manatus, sometimes referred to as "seacow")-a herbivore that was reclassified in 2017, under the authority of the ESA, from "endangered" to "threatened" when total manatee population estimates jumped from a few thousand in 1991 to over 8,000 to 13,000 in subsequent years [U.S. Fish and Wildlife Service (FWS), 2017]. Yet, protections of this marine mammal do not significantly change because habitat fragmentation and loss, noise pollution and other disturbances, and vessel strikes remain as threats. Original image provided by the National Oceanic and Atmospheric Administration (NOAA) (used with permission).

Chapters 2 and 3 are about the diversity of marine mammals and their interaction with humans. Sellheim (2020) talked about whales, seals, polar bears, sea otters, and manatees and mentioned that especially whales and polar bears are often misrepresented or mischaracterized in the public discourse. "The whale," for example, is often ascribed human-like characteristics (e.g., intelligence) that have been used in narratives, movies, and songs. He mentioned that there are about 80-90 different species of which the blue, gray, sperm, and humpback whales were the main targets of commercial whaling operations. Harp seal pups with their "white fluffy fur and large black eyes" were given the image of "innocence," which is used in attempts to limit seal hunt. Furthermore, "the polar bear" is perceived as "the lonely polar bear on a small ice floe ... facing immediate extinction due to climate warming." According to Sellheim (2020), this is misleading because there is not 1 polar bear population but 19 in the polar bear range states, of which 7 are declining, 4 are stable, 1 is increasing, and the status of the remaining 7 is unknown. With regard to manatees (Figure 1), I would like to add that they have been described as "very sweet and gentle giants ... that makes us want to lavish them with affection" (Barry, 2019). Sellheim (2020) also discussed the trend of whale watching and current issues of whale hunting. He talked about the following two motivations for hunting marine mammals: (1) commercial use (commodity to make money) and (2) non-commercial use (to make a living). What I liked about this discussion is that Sellheim presented for each aspect arguments and counterarguments, which is an invitation for a debate. He then discussed other threats to marine mammals, including noise and other pollution, vessel collisions, and bycatch in fishing gear.
Chapters 4-7 include a detailed analysis of the various legal regimes. Sellheim (2020) explored the cooperative landscape and multilateral agreements, which have, as he put it, as the "primary objective the conservation (and from the outset, sustainable use) of biodiversity through the protection and management of specific species." He discussed the ICRW, MMPA, CITES, UNCLOS, and the NAMMCO, ACPB, and Pelagos agreements, among others, and emphasized the importance of marine protected areas (MPAs). He also discussed the quarrels between nations with regards to the hunting and protection of whales, seals, and polar bears.

Sellheim (2020) mentioned in Chapter 8 that the international legal landscape for marine mammals is complex, wide, and scattered, and that other branches of (international) law comprise international marine mammal law. He wants us to understand that "from the earliest days of international, multilateral agreements relating to marine mammals, these agreements were driven by the incentive to exploit them," and that a crucial element of all regimes is its geographic limitation. He concluded this chapter with a discussion about state behavior, aboriginal exemptions, and non-governmental influences, among others.

Sellheim (2020) pointed out in the final chapter that IMML is sometimes controversial and adversarial, which can hinder the drafting of legal documents to protect marine mammals and their environments. He reiterated the key challenges and achievements of the current legal regimes and then presented five interesting scenarios (including one in which not much will change) to envision the future of IMML. He believed that whales, seals, and polar bears will most likely remain iconic species and retain a special place in law, but a shift to a more ecosystem-based management (which includes humans) is clearly appearing.

In my opinion, the book written by Sellheim (2020) is a fascinating read because of the presentation of the diverse views that impact IMML. He clearly demonstrated its complexity, sometimes controversial nature and geographic limitation, and its rather reactive than proactive strategic emphasis. The drawing of Sellheim on multiple perspectives and his critical stance toward the role of socio-legal instruments for the exploitation, protection, and sustainable use of marine mammals leaves the reader ample space for reflection, interpretation, and meaningful policy discussions. If I have any criticism, it would be that more space could have been devoted to the question of morality of marine mammal hunting, which he briefly touched on, for example, in the section on state behavior. Overall, I believe that most readers would find this book interesting, intriguing, insightful, and influential. I recommend IMML as a textbook to students and faculty, as well as a comprehensive volume on marine mammal protection and management to environmental researchers, lawyers, policy-makers, and even lay readers.

\section{AUTHOR CONTRIBUTIONS}

The author confirms being the sole contributor of this work and has approved it for publication. 


\section{REFERENCES}

Barry, L. (2019). Manatees Are No Longer Endangered, but We Still Have Work to Do - Southern Perspective. Available online at https://www.pnj.com/story/ news/2019/08/31/manatees-no-longer-endangered-but-we-still-have-morework-do/2137729001/ (accessed January 14, 2021).

CITES.org. (1975). Convention on International Trade in Endangered Species of Wild Fauna and Flora. Available online at: https://www.fws.gov/international/ cites/

Department of Justice, Canada, (1993). Marine Mammal Regulations. Available online at: https://laws-lois.justice.gc.ca/eng/regulations/sor-93-56/FullText. html

International Whaling Commission (IWC) (1946). The International Convention for the Regulation of Whaling. Available online at: https://iwc.int/convention

National Oceanic and Atmospheric Administration (NOAA) (2020). Marine Mammal Protection. Available online at: https://www.fisheries.noaa.gov/topic/ marine-mammal-protection

North Atlantic Marine Mammal Commission (NAMMCO) (1992). Agreement on Cooperation in Research, Conservation and Management of Marine Mammals in the North Atlantic. Available online at: https://www.nammco.no/topics/ nammco-agreement

Notarbartolo-Di-Sciara, G., Agardy, T., Hyrenbach, D., Scovazzi, T., and Van Klaveren, P. (2008). The pelagos sanctuary for Mediterranean marine mammals. Aquatic Conserv. Mar. Freshw. Ecosyst. 18, 367-391. doi: $10.1002 /$ aqc. 855

Polar Bear Range States (1973). Agreement on the Conservation of Polar Bears. Available online at: https://polarbearagreement.org/index.php/resources/the1973-agreement-on-the-conservation-of-polar-bears/download

Sellheim, N. (2020) . International Marine Mammal Law. Cham: Springer Nature Switzerland AG.
U.S. Fish and Wildlife Service (FWS) (1972). Marine Mammal Protection Act of 1972 as Amended (Through 2018). Available online at: https://www.fws.gov/ international/pdf/legislation-marine-mammal-protection-act.pdf

U.S. Fish and Wildlife Service (FWS) (1973). Endangered Species Act of 1973. Available online at: https://www.fws.gov/endangered/esa-Library/pdf/ESAall. pdf

U.S. Fish and Wildlife Service (FWS) (2017). Endangered and Threatened Wildlife and Plants; Reclassification of the West Indian Manatee From Endangered to Threatened. Available online at: https://www.govinfo.gov/content/pkg/FR2017-04-05/pdf/2017-06657.pdf

United Nations (1982). United Nations Convention on the Law of the Sea (UNCLOS) of 10 December 1982. Available online at: https://www.un.org/depts/ los/convention_agreements/texts/unclos/UNCLOS-TOC.htm

Conflict of Interest: The author declares that the research was conducted in the absence of any commercial or financial relationships that could be construed as a potential conflict of interest.

Publisher's Note: All claims expressed in this article are solely those of the authors and do not necessarily represent those of their affiliated organizations, or those of the publisher, the editors and the reviewers. Any product that may be evaluated in this article, or claim that may be made by its manufacturer, is not guaranteed or endorsed by the publisher.

Copyright (c) 2021 Stadtländer. This is an open-access article distributed under the terms of the Creative Commons Attribution License (CC BY). The use, distribution or reproduction in other forums is permitted, provided the original author(s) and the copyright owner(s) are credited and that the original publication in this journal is cited, in accordance with accepted academic practice. No use, distribution or reproduction is permitted which does not comply with these terms. 